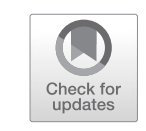

\title{
Yet Another Effort, Citizens, If You Want to Learn How to React!
}

\author{
Kai van Eikels
}

\section{Citizens Who Do Not Want to React}

"Move your fucking head!" The choreographer Deborah Hay calls this one of her core mottoes, in dance and in life. What does this instruction imply if taken for a maxim of performing citizenship? What advice can dance, the art of movement, offer to a body that, normally, is a citizen's body by virtue of reflexes, not reactions? A policeman shouts, 'Hey, you!' and you turn around. This movement suffices to define you as a subject, as one subjected to the state's authority, according to Louis Althusser. ${ }^{1}$ To the extent that citizenship is a legal status, not an achievement or a competence, the only performative utterance demanded from citizens by the state's representatives consists of such small responsive movements of acknowledgment. The more automated, the more reliably locked into behavioral routines these responses are-the fewer signs of a true performance they show - the better, from a statist point of view. Disobedience, in this scenario, is left with only two alternatives. You either ignore the policeman and walk on; or you turn against him and engage in a confrontation, perhaps put up a fight. The police have been trained to deal with either form of insurrection.

\footnotetext{
K. van Eikels $(\bowtie)$

Ruhr-Universität Bochum, Bochum, Germany

(C) The Author(s) 2019

P. Hildebrandt et al. (eds.), Performing Citizenship, Performance

Philosophy, https://doi.org/10.1007/978-3-319-97502-3_2
} 
They will initiate pursuit or check the attack-calling in reinforcements if necessary. But what if citizens learned how to continue the movement of turning their heads around in a way that turns the reflex into a reactionthat changes the situation, slightly but effectively, by using the turnaround as a mode of communication with others, thus referring and relating the policeman's presence to the presence of other citizens - of citizens who understand how to self-organize spontaneously, who are versed in forming a collective, in establishing a civil constellation any time and in any place through a sequence of distributed reactions? For this to happen, moving your head in response would indeed have to become a performance, a bodily activity that draws on skills, on practical and theoretical knowledge. It would need to be practiced as a political movement.

In October 2016, I hosted one day of a week-long workshop initiated by the artist Koki Tanaka. I asked the participants to keep moving all the time and to avoid forming a circle during the entire day we were practicing together. How would power have bearing on a host of people who were incessantly turning around, moving their heads, necks, shoulders and torsos in order to circumvent a standstill and to elude the best-established pattern of gathering? And what kind of power would-or could-it be, as they all continued to be citizens of a nation-state throughout the exercises, remaining subjected to its authority that was operative in their bodies? Which qualities of togetherness would evolve from these bodies' interactions when sustained turnarounds challenged the continuity of unquestioned operation by the standard 'citizen' movement repertoire? The workshop's title, How to Live Together, echoed that of the lecture given by Roland Barthes at the Collège de France in 1976-77.2 The schedule mapped out a variety of activities for the eight volunteers, all of whom lived in or near the city of Münster, Westphalia-some of them were born in the area, some had grown up there but came from an immigrant family, some had only recently arrived for study or to find work. The whole workshop was recorded by a professional film team because the artist wanted a multimedia installation composed of edited videos, photos, texts and objects used during the week to become his contribution for the Skulptur Projekte exhibition in 2017. After we had focused on collectively self-organizing through movement for the first half of our workshop day, the exercises in the second half suggested employing language in a way similar to body movement. For one exercise, nicknamed 'G8,' I told the group members to think of themselves as eight sovereign rulers of the world. Whatever they decided would become reality. All of them were 
equally powerful though. We wrote down a couple of important political topics like 'world peace,' 'solving the hunger problem' and 'tackling sexism,' then selected issues by drawing paper scraps from a pot and addressed them one at a time. Everyone was entitled to make decisions, but one had to react to a decision with another decision. If someone was not satisfied with a decision, they could alter or even annul it with a decision of their own, yet ought to be prepared that the one who had just been overruled might strike back or a third party might come to their aid. For all this wealth of power, the structure called for cooperation among equals; or else, the world management was doomed to fail.

Which it mostly did, for several rounds. While the general atmosphere of mild annoyance never rose to open protest against the rule or against me, the eight participants found it immensely difficult to break away from their conversation habits. They would rather lecture each other: explaining why a decision was wrong or flawed, criticize its ineffectiveness, express ethical indignation, signal sympathy and antipathy (thus creating informal subdivisions of the group), and engage in discussions that promised to be endless. Whereas the task of formulating a decision and deciding on a formulation rendered the citizens-turned-rulers near speechless at times, sophisticated arguments against a decision spouted from their mouths without hesitation. Out of this group of people, some were active with local initiatives helping refugees or had been involved in social activism, and most seemed particularly socially minded. However, the ethos, or even the concept, of help did not cross over to the 'G8' situation; it disappeared as they shared a reality defined by safety, freedom and the power to decide. Emphatic affects to help will likely be triggered in a state of urgency, where others evidently lack something. In A Paradise Built in Hell, Rebecca Solnit tells stories about human beings abandoning their distant attitude after a catastrophe has destroyed or temporarily suspended civil life's infrastructures. ${ }^{3}$ The extreme situation imposed on all draws many closer together. In less dramatic intensity, such encounters under pressure occur every day. But for the leisurely gathered workshop group, whose members had even become acquainted to being filmed on this third day, what motivation was there to help each other?

The pattern shifted a little when I introduced another rule-namely, that every decision was to be made in the form of a 'Yes, and...' 'Yes-Anding' is an agreement in improvisation theater and dance: whatever your response will be, you start with an acknowledgement and affirmation of that which you are reacting to, before adding something. And if you are 
ill-content with what the other one has just said or done, your own reaction needs to redirect it. Negation cannot take on the form of rejection; it will have to find a movement that recognizes the other's move's impulse, following it in its original direction for an initial period, then changing the direction and taking it somewhere else than presumably intended, which may ultimately result in a full turnaround. You react like a Judo or Aikido fighter, who never goes against the partner's movement but uses its momentum for accomplishing their own goal. When we played our game with 'Yes-And-ing,' objections interrupted the collective process less often, and the overall tendency was to be more cooperative and concentrate on modifying a measure rather than trying to disable it.

However, despite the occasional show of pleasure when the process of decision-making was proceeding more smoothly, it remained evident until the end that the participants did not want to react in this manner. They visibly felt at odds with the position of mighty rulers, and the semi-ironic 'G8' likely added to make the effort unattractive. But a similar resistance against communication with and through decisions would, I assume, have manifested without the fiction of unlimited power, which just served the purpose of barring 'impotence' as a pretext for not deciding on something. The influence might as well have been limited to that of an average citizen and the tasks adjusted accordingly. The deeper problem seemed to consist in a collective dynamic that required you to react without offering anything in terms of a compelling situational force: people were safe and free, yet still they had to react. Since they were free, they might as well not react with a decision, instead withdrawing to the position of the critical observer, the member of an audience. Their lives as citizens had trained them for this mode of (non-) participation, therefore it was no surprise that they preferred to remain in this state rather than doing something at which they were inexperienced. In a nation-state with a government of professional politicians, roles are clearly separated between those who make decisions and those who criticize them. Leaving the population with less power to decide puts more emphasis on a kind of criticality that is disconnected from the practical reason of decision-making. The people of a sovereign nation-state may never say 'Yes, and...' to a decision made by the government. The people may not even articulate an Einverständnisan affirmative understanding - which the chorus in Bertolt Brecht's learning play Der Jasager claims is 'most important to learn'4 for living together. They can merely choose between not reacting and critical comments, and both options go hand in hand. 


\section{Citizens Who Had to React Attack Citizens Who Did Not}

New protest movements solved some old problems. In 2011 and 2012, the need for quick decisions in the camps, which were beleaguered by the police, prompted useful techniques for facilitating debates. And the agreement to bring only really controversial issues before the general assembly_ and otherwise let people pursue their own agendas - in addition to speeding up proceedings, helped build a relaxed, trustful atmosphere. ${ }^{5}$ Still, the state of exception defined the occupiers' life in that it provided the problems. Improvised living together consisted of urgent problemsolving, plus free time for sharing knowledge, social activities and discussions about how things would be different in a better world. Whereas external and internal challenges to the protest event created a pressure that called for reactions both effective and efficient, the pastime activitieswhich expressed the freedom of living together in a gathering that was not only protest but an experiment with 'small- $a$ anarchism' - had need to be neither. Organizational improvements, hence, were mostly economic.

This is a well-known phenomenon with improvisation. For the interplay of spontaneous reactions to embrace change-and particularly a change that extends to the collective dynamic's own procedural patternsan extraordinary urgency is required, ideally, a sustained urgency. The much-lauded inventiveness of group improvisation, where 'the new' 'emerges' as a collective surplus, in reality results from a pressure to reinvent that which may be taken for granted in ordinary life. Improvisation's originality reflects a death threat, whose more symbolic manifestations, in everyday extempore and in the performing arts' methods of instant creation, still carry the affective tremor of a literal catastrophe. ${ }^{7}$ And for political activists, this threat is to be taken at face value: They obtain practical knowledge through improvised self-organization because their fights against the authorities of the nation-state often lead to situations in which their enemy denies them basic citizens' rights. They must learn how to react, as the state's executive forces exercise a power to withdraw the privilege of not having to react-the essential privilege of the citizen.

Repeatedly, activism means survival training in a state of suspended citizenship. The acquired reacting skills are therefore often so congenially attuned to situations of duress that they fit in badly with the loose, casual encounters that compose much of citizens' regular social and political undertakings. Once the fighters return to their citizen identities, normality 
swallows the self-organizational know-how. Sometimes they sink back into attitudes of resentment deeper than those who never cried from tear gas attacks. Reserve-the personal stance corresponding to the citizen's right to not react-has lost its innocence for them. Having endured moments, hours or days of unprotected bare life, their bodies are painfully aware that the freedom to hesitate, to defer, to put off, to neglect, to disregard or to remain indifferent to what others are doing is all but a natural given. Something in these bodies continues to fight, taking revenge for the inflicted wound in a kind of precisely misguided transference, when they attack politically like-minded fellow citizens whose behavior betrays their ignorance as to how the open-ended discussions they enjoy so much are only possible because the nation-state spares them the necessity to react.

Can we, politically like-minded fellow citizens, take a cue from that transferred revenge, learning a lesson from the very unfairness of those attacks? As people born and educated into becoming functional entities within a society that never gives its members much reason to ask a question like 'How to live together?,' can we learn how to deal with the nationstate's effective presence in-between our bodies in a similar way to how dance performers work with the material of movement? Althusser's policeman need not be attendant, as long as the citizens hear the state's voice resonate in other citizen's voices - which all but very few of us usually do. We search in vain for an atmosphere that invites direct democracy in a nation-state, if for the reason that there are no direct encounters between its citizens. In peaceful, quiet times, the weight of sovereign authority feels light to the point of sinking into oblivion. Still, every one of us has a primary relationship with the state; and only in second respect, mediated by the state's institutional structures that pervade the entire social sphere, do we entertain relationships with one another. But what to make of this lightness?

\section{Self-Indulgent Citizens Who React Because They Have Practiced Reacting}

Interactions between citizens attest to their indirectness where a certain distance is taken for granted, which the participants experience as their freedom to react because it portends the possibility of not reacting. Citizen behavior expects that the 'together' will be managed. Richard Sennett accused modern individualism of diminishing people's ability to actively 
create the public sphere through the use of formal, respectfully distant, polite, social performing styles. ${ }^{8}$ If such a de-skilling and de-formalization in fact occurred, it has made us even more dependent on a properly separated, buffered co-presence being provided for us by the sovereign authority. What disappeared as people got used to behaving as if in private even when in public-leaving the parade of erect backs for slouched subwayseat ease-is the identification with that authority. Gone are the times when you had to embody the sovereign in your own comportment for others to recognize you as a dignified citizen.

In the progressively nationalist design of a republic, as it was pursued in Europe from the eighteenth to the early nineteenth centuries, the citizens contributed the distance of public converse to the political life. They employed a rhetorical and behavioral code of 'self-abstraction," which effectively removed the distinction between strangers and kin by addressing everyone, even family members or close friends, as though talking to a stranger. The civil public sphere thus socialized the sovereign: a 'bottomup sovereignty' met halfway with the governance from above, reassuring rulers and ruled that the same form of control as it had been implemented top-down in the complex of legislative, judicative and executive power could also be established in citizens' self-organization. From the political party running in national elections down to the local pub's savings association, variants of instituted power proliferated on every level. 'We are the people' translated into 'We are the citizens,' which meant 'We are the state.'

As outmoded (and anachronistic in its sporadic reappearances) as that citizens' pride seems today, it still remains to be discovered what a civic sphere abandoned by sovereignty's poses, postures and paternalisms offers to its residents. What does performing citizenship mean, if it no longer means that citizens embody the sovereign? How can performance benefit from a leisurely state of attendance, if the bodies in public are no longer busy negotiating the discrepancy between the role of the obedient subject-whose every move includes a silent nod to the sovereign's watchman hiding behind-and the role of the substitute sovereign on call, who is always ready to take control ('responsibility') and master a situation? What political performativity is there in the slack, laggard, careless, overly confident but then also more versatile, flip-able, soft-necked inhabitation of a public space maintained by a power that feels exterior to its citizens-by sovereignty that remains un-internalized because the subjects relate to the effects of sovereign power, yet not to its structures? 
This question might be deemed unworthy of asking. Bad conscience hastens to assert that the liberties I take as a 'spineless,' effete $n t h$ generation citizen are not expressions of true freedom; that they betray consumer egotism, complacency and naiveté. If the users of a social network habitually ignore the provider company (unless the service is down), they deserve to be called sheepish, as their lack of vigilance renders them easy targets for manipulation. Does the same not hold for citizens who let the state be the state? We have been alerted to secret services intruding on our privacies on a scale that exceeds darkest fantasy. Never had citizens less reason to trust in the institutional cluster that makes up the state, we might caution one another. But the object-less watchfulness of those many of us who are not hackers, lawyers or other experts ready to fight the battle for privacy with some promise of success is not politically helpful at all. Rather than fortify statist logic by giving ourselves over to an angry, and yet fascinated, distrust, anarchist reaction training would seek to weaken the state as the potential enemy of its citizens by actually taking advantage of some liberties it provides-by utilizing them for the sake of emancipating reacting.

In the pamphlet Français, encore un effort si vous voulez être républicains, embedded in the dialogue La philosophie dans le boudoir, the anarchist de Sade suggested principles for a society in which the revolution achieves a continuous reality, not in the permanent and ever-more radical renewal-as attempted by the Jacobin terreur - but rather in a series of secondary steps that make comprehensive, unrestricted use of the freedoms gained in revolution's initial victory. ${ }^{10}$ In a time when daily news reminds us that democracy might as well not carry on-as one ruler after the other abuses their authority by transforming constitutional democracies into autocratic regimes, and millions of refugees are desperate to reach one of the few remaining states that still seem to respect citizens' rightswe may want to ask ourselves, in de Sade's spirit, what good the protected atmosphere of liberal citizenship affords the political. Especially if we think that the political lies with the people and their power to organize living together-and not with the state's administration-we should expose our political intelligence to the following questions: How can we-you, I, any of us-do something that will feel like a free reaction, based on the sovereign's externality? How can the collective self-organization of political action benefit from a mostly carefree, negligent civil life? Where the state assumes an infrastructural, provider-like reality for its people, what point is 
there in affirming that reality - even though it might be (and, in a certain respect, cannot be anything else) but an illusion?

Performing citizenship - in a blunt interpretation of the expressionis to say that we use knowledge acquired in techniques of artistic performance for instructing citizens on how to play games like ' $G 8$,' how to change them in the playing and how to customize them according to different agendas. If learning to entertain collective processes through nuanced and considered, willful reacting were part of everyone's education, equality would quickly cease to be taken for an ideal upon which reality must surely compromise. More technically, it would be recognized as a performative presupposition that informs communication practices. Criticality, then, would mean adding negations instead of withholding approval. Continuation of movement across multiple bodiescasually, even sluggishly, but perpetually 'moving your fucking head,' as several lines of continuing are synchronizing in and through your body, admitting to the presence of others who happen to be around-would become a widely applied understanding of 'public.' So, inclined to keep on moving, people would see the custom of sitting in circles for hours in order to arrive at a single decision as the weird, quasi-religious ritual it is. ${ }^{11}$

Importantly though, the freedom of not having to react should be respected, more than that, celebrated, within these political skills of performing citizenship. The right to hesitate, to defer, to put off, to neglect, to disregard or to remain indifferent to what others are doing, ought to be the very foundation of an educational program for teaching reaction techniques that set the spine swinging from the feet up to the head down. Rather than scold citizens for their alienation from values like empathy, concern and a type of responsibility that creates bottom-up sovereignty, such performing techniques would do well to scan the alienation for what might be politically helpful in its impact on living together. The more constellative artistry the citizens' bodies achieve in navigating the distance, the more thoroughly performing can establish a civil public sphere. No catastrophic urgency needs be imaginatively imported for this. Unless catastrophes happen, let us find out how to play a peaceful arena, playing it loose. And as soon as we break loose from the compensatory fiction of 'getting closer (again),' foreigners may even touch each other, anytime, in any place. 


\section{Notes}

1. See, Louis Althusser (1971), 'Ideology and Ideological State Apparatuses', in Lenin and Philosophy and Other Essays, trans. Ben Brewster (New York: Monthly Review Press), pp. 121-176.

2. Roland Barthes (2012) How to Live Together. Novelistic Simulations of Some Everyday Spaces, trans. Kate Briggs (New York: Columbia University Press).

3. See Rebecca Solnit (2010) A Paradise Built in Hell: The Extraordinary Communities That Arise in Disaster (London: Penguin).

4. 'Wichtig zu lernen vor allem ist Einverständnis' Bertolt Brecht, Der Jasager, in: Große kommentierte Berliner und Frankfurter Ausgabe, 3 (Frankfurt am Main: Suhrkamp) 1988, pp. 57-65, here p. 57.

5. See David Graeber's account on principles and procedures of decisionmaking with Occupy, in: The Democracy Project: A History, a Crisis, a Movement (Spiegel \& Grau), 2013.

6. See, David Graeber (2000), Direct Action: An Ethnography (Oakland: AK Press), pp. 211-222.

7. See, Kai van Eikels (2016) 'What Your Spontaneity is Worth to Us. Improvisation Between Art and Economics', in Sabeth Buchmann; Ilse Lafer; Constanze Ruhm (eds) Putting Rehearsals to the Test. Practices of Rehearsal in Fine Arts, Film, Theater, Theory, and Politics (Berlin \& Vienna: Sternberg Press), pp. 22-30.

8. See, Richard Sennett (1977) The Fall of Public Man (New York: Knopf).

9. See, Michael Warner (2002) Publics and Counterpublics (Cambridge: MIT Press).

10. See Marquis de Sade, Philosophy in the Bedroom, trans. Richard Seaver and Austryn Wainhouse, pp.91-122, http://www.sin.org/tales/Marquis_de_ Sade\%2D\%2DPhilosophy_in_the_Bedroom.pdf, date accessed l March 2017.

11. On the religious (re-)determination of political gathering, see Kai van Eikels (2016), 'The Togetherness of Those Who Would Not Wait for One Another' in geheimagentur; Martin Jörg Schäfer; Vassilis S. Tsianos (eds) The Art of Being Many. Towards a New Theory and Practice of Gathering (Bielefeld: Transcript), pp. 61-68. 
Open Access This chapter is licensed under the terms of the Creative Commons Attribution 4.0 International License (http://creativecommons.org/licenses/ by $/ 4.0 /$ ), which permits use, sharing, adaptation, distribution and reproduction in any medium or format, as long as you give appropriate credit to the original author(s) and the source, provide a link to the Creative Commons licence and indicate if changes were made.

The images or other third party material in this chapter are included in the chapter's Creative Commons licence, unless indicated otherwise in a credit line to the material. If material is not included in the chapter's Creative Commons licence and your intended use is not permitted by statutory regulation or exceeds the permitted use, you will need to obtain permission directly from the copyright holder.

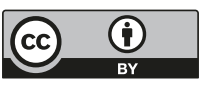

